\title{
CHRIST AND CONTROVERSY
}

The perennial question of the relation between these two, especially in dealing with Moslems, has been again raised by Dr. Sherwood Eddy in his article on "The Christian Approach in the Near East," in the April number of the International Review of Missions. It is worthy of further discussion, and in default of being a missionary actually now in the field, I offer these considerations.

The too brief sketch given by Dr. Eddy of his recent work among Moslems and Christians in Egypt and Turkey is much more than interesting: it warms the heart and strengthens the faith and kindles the hope of the lover of Christ and His Kingdom, and it calls forth earnest prayer for an ever increasing blessing on the efforts of this God-called evangelist. During five weeks in Egypt and four weeks in Turkey, Dr. Eddy spoke to many thousands of the educated classes, including a considerable number of Moslems, and he found that a constructive message of God in Christ and the call to discipleship met with a remarkable response, apparently without the emergence of those controversial questions which so frequently bar or deflect the impact of the gospel message. On this Dr. Eddy bases a strong appeal to abandon the polemic method which has been tried and found wanting for the eirenic approach, the positive presentation of Christ as the Saviour without mention of the points wherein the Moslem doctrine of Christ or any other tenet of Islam differs from the Gospel. A group of workers which met at the close of the month of meetings advocated the application of the same principle to literature, including the maxim: "Mohammed will have to be left severely alone"; they added: "The only literature for Moslems which should be suffered to remain is literature of a suasive informatory type, e. g., invitations to read 
the Bible, studies of aspects of the redemptive work of Christ."

The case seems a simple one on general principles. Religion, which claims to be the influence that binds men to God, ought to be the most effective power for uniting them with one another, yet in practice how largely it has been and is a potent source of disunion! Controversy is that aspect of religious conviction which chiefly promotes strife, therefore do away with controversy. But the situation is not so simple either in the New Testament, to which Dr. Eddy appeals, or in contemporary work among Moslems.

To take Scripture. When Dr. Eddy writes of our Lord and His Apostles "they were not debaters, but witnesses," he overlooks some clear features of their portrayal in the New Testament. In the Synoptical Gospels Jesus is repeatedly seen in controversy with Pharisees and Sadducees alike, and at the bar of the high priest the supreme controversy as to His divine sonship is pressed to the point of death. In St. John's Gospel, still more, $\mathrm{He}$ is engaged in long-drawn controversy with "the Jews." St. Paul at Athens "reasoned in the synagogue with the Jews and in the market-place every day with them that met with him." At Ephesus he reasoned daily in the school of Tyrannus, and he will be a unique missionary to Moslems in the twentieth century who can escape from discussion with them on the doctrines and practices which they have inherited from the Jew, and according to the logic which they received from the Greek; assuming that he follows up his message by daily personal contact with them in their own language and the characteristic atmosphere of their own thought.

It is here, I venture to suggest, that we come across the limitations of the eirenic principles, which Dr. Eddy so strongly and persuasively advocates. If the words "Christian approach" are used in a strict sense of the first presentation of the gospel message, there are few missionaries who would not agree that this must be positive 
and not controversial. And this method is specially suited to short courses of evangelistic addresses, such as those under consideration. I have myself taken part in such meetings which were held in Lahore, especially for Moslem students. These were attended in great numbers, and the addresses were afterwards followed by private informal discussions in a smaller room, at which special difficulties were raised and explained. But as soon as the question is asked: "Who is this Jesus whom I am to trust for salvation?" others inevitably follow: "What is His relation to the earlier prophets? to God? to Mohammed?" The seeker first clings to the idea that somehow he can hold to Christ and Mohammed as saviours; then the painful question forces itself to the front: Christ or Mohammed? That so great an issue should be decided without marshalling the issues on either side is impossible in the case of the thoughtful seeker, and that marshalling is controversy.

In this sense the method of controversy, informed by the Spirit of Christ, and carried on by men whose holiness of life enforced their message, has not been found wanting, either in preaching or literature. In $1854 \mathrm{Karl}$ Gottlieb Pfander and Thomas Valpy French met two Moslem scholars, Rahmatullah and Wazir Khan in discussion at Agra. The debate lasted for two days, and, as often happens, both sides claimed the victory. Some years passed, then two of the younger scholars who had helped the Moslem champions came out for Christ. One of them was Imad ud-Din, of Panipat and Amritsar, who gave himself to the work of literature, and carried on for many years a trenchant polemic against Islam, till at length he felt that the ground had been covered, and betook himself to work for the edification of the Church. His style of controversy is uncompromising. He once remarked to me of it: "I want to make the Mussulman feel on what a kacha (weak) foundation his faith is resting." But he was very far from leaving out the message of Christ as the loving Saviour who had brought peace to his own soul. 
In the various conversations of educated Moslems that I have personally known, the writings of Dr. Imad ud-Din come in at one stage or another, sometimes at the very beginning. The other young assistant at the Agra disputation was Maulawi Safdar Ali, afterwards a government official. He, after his baptism, wrote the Niyaznama or Respectful Letter, the gentle, though by no means indecisive, style of which is in marked contrast to the pointed challenge of Imad ud-Din. That work too has been most useful in leading Moslems to Christ, but it would be most difficult to say which of these two sons of controversy has been the more used in this way, except that Imad ud-Din covered a wider field. One of the two leaders in the Agra disputation, Bishop French, did not write much; his influence was chiefly that of the teacher and the saint. Dr. Pfander, on the other hand, was the author of several weighty controversial books. The chief of them is Mizan "l-Haqq, or the Balance of Truth, which has remained the leading work in the controversy ever since. Originally written in German, it was translated into English, Persian, Urdu, Marathi, Turkish, Arabic, and it may be, other languages that $I$ do not know of. Of late years it has been revised and brought up-to-date by Dr. Tisdall, and published in English by the Religious Tract Society, London, who generously furnish free copies to missionaries who need it for their work. With equal candor and courtesy Dr. Pfander here sets forth the authenticity of the Old and New Testament, and the principal doctrines contained in them, followed by "a candid inquiry into the claim of Islam to be God's final revelation." I can remember no conversion of a thoughtful Moslem in which this book has not played some part. Recently, we hear, it is being eagerly read in Palestine. As a matter of experience, no less than of reason, controversy of the right kind has had, and is likely to retain, an essential place in missionary work among Moslems, as among other religions also. After all, a man does not elect to follow one leader rather than another because of their similarities, 
but because of their differences, and if we call upon a man to love God who has revealed His love in Christ, we call upon him to love God with his mind as well as with his heart.

But to maintain this is not to say that Dr. Eddy's warning is not timely and useful. Just because the issue between Christianity and Islam is so plain, and the argument for the Biblical revelation as compared with the Koranic so irrefragable, there is real danger of our working mainly on the line of intellectual conviction, and a conversion based primarily on reason, however sound the arguments, is unstable, though, or because, it produces a keen and effective type of controversialist. I think of one such case, a man of keen nimble intellect, and in his grade one of our best teachers. He had arrived at conversion not without personal influence, but by a clear logical process. He frequently assisted in bazar preaching, by preference in the discussion that would come up, do what we might to be "constructive." I still see the contemptuous smile with which he would produce his Koran and demolish the objector with a well chosen passage. But after some years there came monetary difficulty, quarrels with the missionary and other Christians, social pressure and offer of preferment and he fell away. The conversion that has no element of passion in it, whether of sorrow for sin or of love for Christ, lacks the deep root that can maintain life under adverse influences. When these are brought to bear, it is not over difficult for the convert by reason only to add to his previous stock another argument which will serve to show that the first are modified by new considerations.

How then can this response of the soul to God be awakened in the Moslem or any other man? From the human side only through a divine desire in the messenger manifested in a true human fellowship. The Father seeketh; the Son of Man came to seek and to save; the Spirit and the Bride say: Come, take of the water of life freely; and that is life in all its human, as well as divine, relations. 
Here, surely, we see the secret of the influence of Dr. Eddy's testimony. The Oriental perceives a man who sympathizes with his aspirations and ideals, who feels where he is galled by failure and thwarted by impotence, and who wants to tell him the secret of the power that he has found available in his own like needs, so the message of the incomparable Prince of Life gains a footing not only in his mind but in his heart, and that assuredly will be the attitude in which he may hopefully enter on the painful struggle which will generally follow. This method was the one followed by the greatest evangelist of Moslems that I have known, Rowland Bateman, of Narowal. His approach was not without discussion, but more through plain teaching of the Bible, and most through human fellowship in games and sports, in daily avocations, in personal service at times of sickness and other need, but he never urged or even suggested baptism, nor discussed the sacrament, till it was asked for with unmistakable desire to be united to Christ. The fruits of that method may be seen today in leading members of the Church in the Punjab.

But, having said this, there remains a danger to be guarded against in stressing the constructive presentation of the message to Moslems as if it had no limitations. I say this because I have myself experienced the danger, and seen others do so. Seeing that the Moslem acknowledges the authority of the Old and New Testaments, at least in theory, and that the proof of their genuineness as against the Koranic perversions is so very plain, it is easy for the missionary to say that Mohammed must be left severely alone and to ride off on a purely scriptural message without considering the reasons why, to the people whom he wants to draw to Christ, Mohammed is the last of the prophets who has superseded Him. It requires much less sweat of brow and brain to do this than to write, or even follow the argument of, an article like "Mohammed without Camouflage" on the character of the Prophet by Canon Gairdner in this quarterly (Vol. IX, 
No. I). But any one who will read that article with care, will see how needful it is to have this side of the truth exhibited in its place, as well as the picture of the Christ in $\mathrm{H}$ is winning power. If we want the Moslem, as we do, to share with us the best possession that we have, then faithfulness to fact must be an essential element.

Happily it is not necessary that controversy should be only destructive. One of my ablest and most successful colleagues was an ex-Moslem Panjabi, who had come to a knowledge of the truth in the first instance by a study of the New Testament given him by his master to help him in confuting the Christians. He was always a model of courtesy and fairness in his preaching and conversations with Moslems, and later as an ordained man he was repeatedly invited to address a congregation of Moslems in their mosque. Being challenged by a town maulawi on a certain occasion to a public disputation in his mosque, he agreed, but only on condition that there should be no thrust and counter-thrust of argument, but that first a subject should be selected, such as salvation from sin, and that the maulawi and the padri in turn should each expound for five minutes the teaching of his scripture on it. The result soon showed the emptiness of the one as compared with the other, and the sun was barely set when the maulawi announced that it was high time for evening prayers, ${ }^{1}$ and that urgent business would prevent resumption of the discussion. This symposium method is, I believe increasingly in use among both Christians and non-Christians, and gives scope for the constructive elements. The discussion, the lecture, the simple address, the friendly talk-each has its fruitful place in the evangelistic message provided that the onc Spirit animates all.

What I have written has reference largely to Indian conditions. Perhaps it may be supplemented by experiences from other quarters.

London.

H. U. WEITBRECHT STANTON.

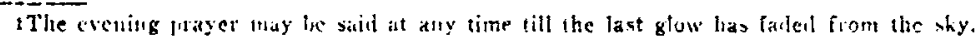

